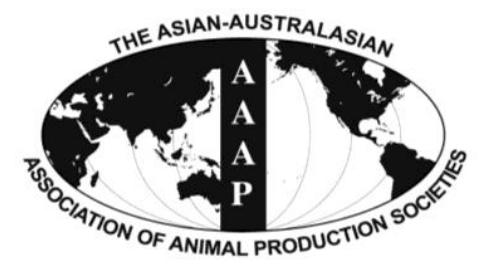

Asian Australas. J. Anim. Sci.

Vol. 26, No. 7 : 971-980 July 2013

http://dx.doi.org/10.5713/ajas.2012.12627

www.ajas.info

pISSN 101 1-2367 elSSN 1976-5517

\title{
Use of Dried Stoned Olive Pomace in the Feeding of Lactating Buffaloes: Effect on the Quantity and Quality of the Milk Produced
}

\author{
S. Terramoccia*, S. Bartocci, A. Taticchi ${ }^{1}$, S. Di Giovanni, M. Pauselli ${ }^{2}$, \\ E. Mourvaki ${ }^{2}$, S. Urbani ${ }^{1}$, and M. Servili ${ }^{1}$ \\ Consiglio per la Ricerca e la Sperimentazione in Agricoltura, \\ Centro per la Produzione delle Carni ed il Miglioramento Genetico, Via Salaria 31, 00015 Monterotondo, Rome, Italy
}

\begin{abstract}
Dried stoned olive pomace (DSOP) was administered to dairy water buffaloes, and their productive performance and milk composition were analysed. Sixteen pluriparous lactating buffaloes were divided into two uniform groups (control and experimental), taking into consideration the following parameters: milk production $(2,192$ and 2,102 $\mathrm{kg}$ ) and duration of lactation (254 and $252 \mathrm{~d}$ ) of the previous year, distance from calving (51 and $43 \mathrm{~d}$ ), milk production ( 9.71 and $10.18 \mathrm{~kg} / \mathrm{d}$ ), body condition score (BCS) (6.44 and 6.31) and weight ( 617 and $653 \mathrm{~kg}$ ) at the beginning of the trial. Both diets had the same formulation: second cut alfalfa hay $20 \%$, corn silage $42 \%$, concentrate $38 \%$ but the two concentrates differed in their formulation, the experimental one contained $15.50 \%$ of DSOP as fed. The employed DSOP showed high amounts of secoiridoids, such as 3,4-dihydroxyphenylethanol (3,4-DHPEA) (1.2 g/kg DM), 3,4-dihydroxyphenylethanol-elenolic acid di-aldehyde (3,4-DHPEA-EDA) (12.6 g/kg DM), p-hydroxyphenylethanol-elenolic acid di-aldehyde (p-HPEA-EDA) (5.6 g/kg DM) and lignans, which are known to be powerful bioactive compounds. The control diet had an energy-protein content of 0.86 Milk FU/kg DM and $143.3 \mathrm{~g} / \mathrm{kg}$ DM of crude protein, whereas the experimental diet of $0.87 \mathrm{Milk}$ FU/kg DM and $146.6 \mathrm{~g} / \mathrm{kg} \mathrm{DM}$ of crude protein. Each animal of the two groups received $17 \mathrm{~kg} \mathrm{DM} / \mathrm{d}$ and each buffalo of the experimental group, by way of the concentrate, ingested $1.05 \mathrm{~kg}$ DM/d of DSOP. The trial lasted 40 days. No significant difference was found between the BCS (6.41 and 6.53), live weight (625.93 and $662.50 \mathrm{~kg}$ ) and milk production $(9.69$ and $10.08 \mathrm{~kg} / \mathrm{d}) \mathrm{of}$ the two groups, as was the case for fat, protein, lactose, $\mathrm{pH}$ and coagulating parameters of the two milks. The milk fat of the experimental group had a significantly higher content of total tocopherols ( $10.45 \mathrm{vs} 8.60 \mu \mathrm{g} / \mathrm{g}, \mathrm{p}<0.01)$ and retinol (3.17 vs $2.54 \mu \mathrm{g} / \mathrm{g}, \mathrm{p}<0.01)$. The content of the reactive substances with tiobarbituric acid (TBARs) was significantly lower in the milk fat of the experimental group (12.09 vs $15.05 \mu \mathrm{g} \mathrm{MDA} / \mathrm{g}, \mathrm{p}<0.01)$. The acid content of the milk fat of the experimental group had a significantly higher content $(\mathrm{p}<0.05)$ of C18:0 and of C18:3 $\omega 6$. LC-MS/MS analysis showed the presence of 3,4-DHPEA (36.0 $\mu \mathrm{g} / \mathrm{L})$ in the milk of the DSOP-fed buffaloes, while other phenols were not found. DSOP, in the quantity utilized, can be used in the feeding of the lactating buffalo; the dieteticnutritional characteristics of the milk are improved due to a greater contribution of tocopherols, retinol and the presence of hydroxytyrosol. (Key Words: Dried Stoned Olive Pomace, Buffalo, Milk Production and Quality)
\end{abstract}

\section{INTRODUCTION}

Olive growing is widespread not only in the area of the Mediterranean basin, but also in the United States, Australia, South Africa and China; however, $75 \%$ of the world

\footnotetext{
* Corresponding Author: S. Terramoccia. Tel: +39-6-900901, Fax: +39-6-9061541, E-mail: stefano.terramoccia@entecra.it ${ }^{1}$ Dipartimento di Scienze Economico-Estimative e degli Alimenti, Sezione di Tecnologie e Biotecnologie degli Alimenti, Università degli Studi di Perugia, Via S. Costanzo, 06126 Perugia, Italy.

${ }^{2}$ Dipartimento di Biologia Vegetale e Biotecnologie Agroambientali e Zootecniche, Università di Perugia, Borgo XX Giugno 74, 06123 Perugia, Italy.

Submitted Nov. 8, 2012; Accepted Jan. 17, 2013; Revised Mar. 21, 2013
}

production of olive oil is concentrated in Southern Europe where the main producers are Spain $(45 \%)$, Italy (31\%) and Greece (22\%) (Molina-Alcade and Yañez-Ruiz, 2008). Twenty percent of the yield of olive processing is in oil, the remaining $80 \%$ is made up of pulp, nut, skin and water (Weinberg et al., 2008). The fresh pomace, which represents approximately $50 \%$ of the conversion process (Servili et al., 2011), is largely not utilized and creates costs for its disposal and problems related to environmental impact. Italian agriculture focuses on product quality in order to improve product placement; this also occurs in the olive oil sector, where extraction technology based on preventive stoning of the olives allows for improved quality of the oil 
favouring through control of peroxidase, an enzyme concentrated in the kernel, that degrades the phenolic compounds during the extraction process. This determines an increase in phenolic compounds not only in the oil but also in the corresponding virgin stoned pomace (Servili et al., 2007). Up until a few years ago, the virgin pomace was used for extraction, using solvents, of second quality oil for domestic food use. Currently there is limited consumer interest in pomace oil, consequently the virgin pomace must be largely disposed of as a residue. The virgin stoned pomace, obtained through this extraction cycle, has a lower lignin content with a good lipid content, this leads to improved digestibility (Sadeghi et al., 2009). Other aspects that should be noted are: a fatty acid composition of merit for its high content of oleic acid, a balanced composition of polyunsaturated fatty acids, the presence of antioxidants such as tocopherols and retinol and high amounts of bioactive phenols such as secoiridoids and lignans (Servili et al., 2007). For these characteristics this by-product can be used, after drying, in the feed industry. The drying process applied to the olive pomaces has been proposed as an innovative way to guarantee sound preservation of the seasonal product over an extended period of time (Vera et al., 2009).

Nutritional science is concerned with those food components, even when present in small quantities, that play a fundamental role in human nutrition, ensuring a better quality and length of life. Feeding lactating ruminants with virgin stoned pomace, with an acidic composition of merit, containing a-tocopherol, retinol and phenol can bring about positive variations in the quality of the milk produced, both with an improvement in the acidic composition of the lipid fraction and with oxidative stability (Chiofalo et al., 2004; Pauselli et al., 2007). Bearing in mind that in some countries of the Mediterranean basin and the Black Sea region (Italy, Albania, Bulgaria, Greece, Romania, Turkey, Syria and Egypt) buffalo species (Borghese and Mazzi, 2005) coexists with olive oil production, and that this species has also been introduced in Spain (Bartocci et al., 2002). Moreover, considering the characteristics of the byproducts (Molina-Alcade and Yañez-Ruiz, 2008) and that the buffalo digests protein better than the bovine in diets with a high content of structural carbohydrates (Puppo et al., 2002), the utilization of lactating buffaloes for this trial was deemed appropriate.

The aim of this study was to examine i) the possible use of dried stoned olive pomace in the diet of the lactating buffalo, ii) the effect on the quantity-quality of the milk produced.

\section{MATERIAL AND METHODS}

\section{Production of dried stoned olive pomace}

Fresh pomaces were obtained by mechanical extraction of virgin olive oil using the following procedure. The olives were stoned and malaxed for $40 \mathrm{~min}$ at $25^{\circ} \mathrm{C}$. The oil extraction was performed using an RCM Rapanelli threephase decanter, mod. 400 eco. The stoned pomaces were stored at room temperature for a maximum of $36 \mathrm{~h}$ before drying.

The following optimum process for the drying of dried stoned olive pomaces (DSOP) in order to safeguard the phenolic composition and reduce the oxidative processes on the fatty fraction was defined by Servili et al. (2007). The pomaces were dried using a fluid-bed dryer. The initial temperature of the flow of drying air was $120^{\circ} \mathrm{C}$ and the maximum temperature of the pomaces during the drying process was $45^{\circ} \mathrm{C}$. After drying, the DSOP were stored at room temperature.

\section{Animals and diets}

Sixteen pluriparous Mediterranean buffaloes (Bubalus bubalis, L.) were used, divided at the beginning of the trial into two uniform groups (control and experimental) of 8 animals. The two groups were not statistically different for the following parameters: milk production (2,192 and 2,102 $\mathrm{kg}$ ) and duration of the lactation (254 and $252 \mathrm{~d}$ ) of the previous year; distance from calving (51 and $43 \mathrm{~d}$ ), milk production (9.71 and $10.18 \mathrm{~kg} / \mathrm{d})$, body condition score (BCS) (6.44 and 6.31) and weight (617 and $653 \mathrm{~kg}$ ) at the beginning of the trial. The trial lasted $40 \mathrm{~d}$. The animals were weighed at the beginning and the end of the trial and the nutritional status was determined using the BCS, utilizing the scale of Wagner et al. (1988) modified, for the buffalo species, by Campanile et al. (1998). This method provides for the use of a score from 0 to 9 . The feedstuffs used were second cut alfalfa hay, corn silage and two concentrates especially formulated using the same feed materials (Table 1), the experimental concentrate contained DSOP (15.50\% as fed). The control and experimental diets were isoenergetic and isoprotein (Table 3), the control diet $=0.86$ Milk FU $/ \mathrm{kg} \mathrm{DM}$ and $143.3 \mathrm{~g} / \mathrm{kg} \mathrm{DM}$ of crude protein, experimental diet $=0.87$ Milk FU $/ \mathrm{kg} \mathrm{DM}$ and $146.6 \mathrm{~g} / \mathrm{kg}$ DM of crude protein. The control and experimental

Table 1. Formulation of the two concentrates (\% as fed)

\begin{tabular}{lcc}
\hline & Control & Experimental \\
\hline Bran flour & 27.00 & 20.00 \\
Maize flour & 21.00 & 25.00 \\
Soya extract flour & 12.00 & 15.00 \\
Flour from distillery residues & 10.00 & 5.00 \\
Flour of dehydrated alfalfa & 10.00 & - \\
Flour from sunflower extract & 9.00 & 12.00 \\
Flour from beet pulp & 3.50 & - \\
Flour from stoned olive pomace & - & 15.50 \\
Molasses & 3.00 & 3.00 \\
Vitamin-mineral supplementation & 4.50 & 4.50 \\
\hline
\end{tabular}


concentrates had a net energy content of 0.98 and 1.01 Milk FU/kg DM and of crude protein of 189.6 and $198.3 \mathrm{~g} / \mathrm{kg}$ DM respectively. Both the diets had the following formulation dry matter basis: second cut alfalfa hay $20 \%$, maize silage $42 \%$, concentrate $38 \%$. The feeding was by group and the feed was given as a mixed ration once a day. Each animal of two groups received $17 \mathrm{~kg} \mathrm{DM} / \mathrm{d}$ and $1.05 \mathrm{~kg} \mathrm{DM} / \mathrm{d}$ of DSOP was administered to each buffalo in the experimental group, which represented $6.17 \%$ of the diet.

\section{Chemical analyses of animal feeds}

The following analytical determinations were performed on feedstuff used in the experiment: dry matter (DM), crude protein $(\mathrm{CP})$, crude fibre $(\mathrm{CF})$, ether extract (EE) and ash (AOAC, 1995); neutral detergent fibre (NDF), acid detergent fibre (ADF) and acid detergent lignin (ADL) according to the method reported by Goering and Van Soest (1970). The non-structural carbohydrates were calculated according to the method reported by Van Soest et al. (1991). The net energy of each feedstuff, expressed as Milk FU/kg DM, was determined using the chemical composition and digestibility of the organic matter (INRA, 1988). The different parameters of the chemical composition and net energy of the two diets were calculated proportionately to their percentage in the component feedstuffs. Table 2 presents the chemical composition, the net energy, the fatty acids profile and the phenolic compounds of the DSOP. Table 3 reports the chemical composition and net energy of the feedstuffs and of the diets employed.

The phenolic compounds of DSOP were extracted and analysed by HPLC-DAD/FLD following the procedure previously described by Servili et al. (2011), using $10 \mathrm{~g}$ of the sample. To extract the residual oil from the DSOP, 250 $\mathrm{ml}$ of hexane was added to $100 \mathrm{~g}$ of DSOP. The mixture was homogenized with the T50 Ultraturrax at 6,000 rpm for $10 \mathrm{~min}$ at $20^{\circ} \mathrm{C}$ and then filtered with filter paper. The extraction was performed twice. The filtered homogenate was evaporated under vacuum in a nitrogen flow at $35^{\circ} \mathrm{C}$. In the residual oil, the acidic composition was determined according to the 1989/03 Commission Regulation (2003). Feed fatty acid composition was ascertained by gas
Table 2. Dry matter ( $\mathrm{g} / \mathrm{kg}$ as feed), chemical composition $(\mathrm{g} / \mathrm{kg}$ $\mathrm{DM}$ ), net energy (Milk FU/kg DM), fatty acid profile (\%) and phenolic compounds $(\mathrm{g} / \mathrm{kg} \mathrm{DM})$ of dried stoned olive pomace (DSOP)

\begin{tabular}{lc}
\hline Composition & \\
\hline $\mathrm{DM}$ & 956.7 \\
$\mathrm{CP}$ & 100.9 \\
$\mathrm{CF}$ & 184.1 \\
$\mathrm{EE}$ & 206.6 \\
$\mathrm{NSC}$ & 195.3 \\
$\mathrm{Ash}$ & 75.6 \\
$\mathrm{NDF}$ & 421.6 \\
$\mathrm{ADF}$ & 329.2 \\
$\mathrm{ADL}$ & 207.8 \\
$\mathrm{NE}$ & 0.70
\end{tabular}

Fatty acids profile

$\begin{array}{lr}\text { C14:0 } & 0.1 \\ \text { C16:0 } & 12.3 \\ \text { C16:1 } & 0.9 \\ \text { C17:0 } & 0.1 \\ \text { C18:0 } & 1.9 \\ \text { C18:1n9 } & 75.5 \\ \text { C18:2n6 } & 8.3 \\ \text { C18:3n3 } & 0.6 \\ \text { C20:0 } & 0.2 \\ \text { C20:1n9 } & 0.3 \\ \text { Phenolic compounds } & \\ \text { 3,4-DHPEA } & 1.2 \\ \text { p-HPEA } & 0.9 \\ \text { Verbascoside } & 10.0 \\ \text { 3,4-DHPEA-EDA } & 12.6 \\ \text { p-HPEA-EDA } & 5.6 \\ \text { (+)-1-Acetoxypinoresinol } & 0.2\end{array}$

$\mathrm{DM}=$ Dry matter; $\mathrm{CP}=$ Crude protein; $\mathrm{CF}=$ Crude fibre $\mathrm{EE}=$ Ether extract; $\mathrm{NSC}=$ Non-structural carbohydrates; $\mathrm{NDF}=$ Neutral-detergent fibre; $\mathrm{ADF}=$ Acid-detergent fibre; $\mathrm{ADL}=$ Acid-detergent lignin $; \mathrm{NE}=$ Net energy; 3,4-DHPEA = 3,4-Dihydroxyphenylethanol; p-HPEA = p-Hydroxyphenylethanol 3,4-DHPEA-EDA = 3,4-Dihydroxyphenylethanol-elenolic acid di-aldehyde; p-HPEA-EDA = p-Hydroxyphenylethanol-elenolic acid di-aldehyde

chromatography, as methyl ester derivatives after transesterification with sulphuric acid. A MEGAL FISONS

Table 3. Dry matter (g/kg as fed), chemical composition (g/kg DM) and net energy (Milk FU/kg DM) of the feedstuffs and of the two diets utilized

\begin{tabular}{lcrcccccccc}
\hline & DM & \multicolumn{1}{c}{ CP } & CF & EE & NSC & Ash & NDF & ADF & ADL & NE \\
\hline Alfalfa hay & 879.6 & 179.9 & 339.2 & 27.1 & 207.2 & 85.3 & 500.5 & 385.1 & 87.6 & 0.67 \\
Maize silage & 334.2 & 83.9 & 216.7 & 24.8 & 327.9 & 46.9 & 516.5 & 259.0 & 44.9 & 0.83 \\
Control concentrate & 907.3 & 189.6 & 124.4 & 29.7 & 366.0 & 99.8 & 314.9 & 175.3 & 65.5 & 0.98 \\
Experimental concentrate & 912.5 & 198.3 & 124.7 & 47.5 & 348.2 & 84.8 & 321.2 & 168.6 & 78.2 & 1.01 \\
Control diet & 661.1 & 143.3 & 206.1 & 27.1 & 318.2 & 74.7 & 436.7 & 252.4 & 61.3 & 0.86 \\
Experimental diet & 663.1 & 146.6 & 206.2 & 33.9 & 311.4 & 69.0 & 439.1 & 249.9 & 66.1 & 0.87 \\
\hline
\end{tabular}

$\mathrm{DM}=$ Dry matter; $\mathrm{CP}=$ Crude protein $\mathrm{CF}=$ Crude fibre; $\mathrm{EE}=$ Ether extract; $\mathrm{NSC}=$ Non-structural carbohydrates;

$\mathrm{NDF}=$ Neutral-detergent fibre; $\mathrm{ADF}=$ Acid-detergent fibre; $\mathrm{ADL}=$ Acid-detergent lignin; $\mathrm{NE}=\mathrm{Net}$ energy. 
gas chromatographic apparatus was equipped with a detector and a capillary column (D-B Wax $30 \mathrm{~m}$ in length, $0.25 \mathrm{~mm}$ in thickness and $0.25 \mu \mathrm{m}$ in thickness of the internal film) with helium as the carrier gas. The temperature was programmed at $130^{\circ} \mathrm{C}$ for $5 \mathrm{~min}$ followed by an increase to $230^{\circ} \mathrm{C}$ at a rate of $20^{\circ} \mathrm{C} / \mathrm{min}$. The temperatures of the injector and detector were $270^{\circ} \mathrm{C}$ and $260^{\circ} \mathrm{C}$, respectively. The peak areas of the individual fatty acids were identified by means of previous fatty acid standard injection (Sigma-Aldrich) and quantified as a percent of total fatty acids.

The extraction of tocopherols, tocotrienols and retinol from the feeds was carried out according to the method of Havemose et al. (2004), by means of chromatography.

\section{Milk yield and chemical analyses}

Milk production, representative of two milkings at intervals of $12 \mathrm{~h}$, was determined at the beginning of the trial and after 15, 30 and $40 \mathrm{~d}$. The individual milk samples, representative of the two milkings, taken at each control, underwent the following analytical determinations: fat, protein (Nx6.38), lactose, urea and pH (ASPA, 1995). The parameters for milk coagulation were determined: rennet clotting time $(r)$, curd firming time $\left(\mathrm{K}_{20}\right)$, curd firmness $\left(\mathrm{A}_{30}\right)$ by means of the thromboelastograph Formagraph as reported by Zannoni and Annibaldi (1981). In order to estimate the quantity of mozzarella cheese produced daily, the equation proposed by Altiero et al. (1989) was used.

The milk fatty acid composition was evaluated by gas chromatographic analyses as were the methyl ester derivatives after transesterification with sulphuric acid following the procedure reported above for feed samples. To evaluate the risk of coronary disease, atherogenic and thrombogenic indexes were calculated as suggested by Ulbricht and Southgate (1991). Tocopherol, tocotrienol and retinol extraction was conducted according to the method proposed by Havemose et al. (2004). The reactive substances with tiobarbituric acid (TBARs), expressed as $\mu \mathrm{g}$ MDA/g of fat, were determined (Fenaille et al., 2001). At the end of the trial, a milk tasting was carried out on the bulk of the milk produced by the two groups in order to verify any differences regarding the flavour and its persistence, in addition any variations regarding colour and smell were also assessed (Risvik et al., 1989).

\section{Extraction and analysis of the phenolic compounds from milk}

The milk sample $(80 \mathrm{ml})$ was skimmed by centrifuging at 5,000 rpm for $1 \mathrm{~min}$ at room temperature. A volume of 60 $\mathrm{ml}$ of skimmed milk was acidified with a solution of citric acid $(1.5 \mathrm{M})$ to $\mathrm{pH} 4.6$ to precipitate the caseins. Then, 120 $\mathrm{ml}$ of methanol was added to the sample, and after $1 \mathrm{~min}$ of vortex mixing, the solution was centrifuged at 5,000 rpm for 2 min. The supernatant was filtered with a fluted filter. The precipitate was washed with $80 \mathrm{ml}$ of a mixture of methanol and water $(80: 20, \mathrm{v} / \mathrm{v})$, and after $1 \mathrm{~min}$ of vortex mixing, the solution was again centrifuged at 5,000 rpm for $2 \mathrm{~min}$. The supernatant was filtered and collected with the previous fraction (this operation was repeated twice). The methanol was removed with a rotary vacuum evaporator at $37^{\circ} \mathrm{C}$, and the aqueous extract was passed through an Extract-cleanTM SPE C18-HC column $(5,000 \mathrm{mg} / 25 \mathrm{ml})$ that was activated and conditioned with $10 \mathrm{ml}$ of methanol and $10 \mathrm{ml}$ of water, respectively. The column containing the analyte was washed with $10 \mathrm{ml}$ of water. The phenolic compounds were eluted with $100 \mathrm{ml}$ of methanol, and the collected fraction was mixed with $40 \mathrm{ml}$ of hexane in a separatory funnel. After agitation, the methanolic fraction was transferred to the rotary vacuum evaporator to eliminate the solvent. The residue was reconstituted in $5 \mathrm{ml}$ of methanol, filtered with a $0.2 \mu \mathrm{m}$ PVDF filter (Alltech, Deerfield, IL, USA), dried under a flow of $\mathrm{N}_{2}$ gas and recovered with $1 \mathrm{ml}$ of methanol for LC-MS/MS analysis.

For LC-MS/MS analysis, $20 \mu \mathrm{l}$ aliquots were injected into an HPLC system consisting of two 218 pumps and a Varian 1,200 L triple-quadrupole mass spectrometer equipped with an electrospray ionization interface (Varian, Palo Alto, CA, USA). A Varian C18 Intertsil ODS-3 column $(250 \times 4.6 \mathrm{~mm}, 5 \mu \mathrm{m})$ was used as the HPLC column. Elution was performed at a flow rate of $1.0 \mathrm{ml} / \mathrm{min}$ using a mixture of water/acetic acid (99.8:0.2 v/v) (solvent A) and methanol (solvent B) as mobile phases. The gradient was changed as follows: to $95 \%$ solvent A for $2 \mathrm{~min}$, to $75 \%$ solvent $\mathrm{A}$ in $8 \mathrm{~min}$, to $60 \%$ solvent $\mathrm{A}$ in $10 \mathrm{~min}$, maintained for $2 \mathrm{~min}$, to $100 \%$ solvent $\mathrm{B}$ in $4 \mathrm{~min}$, maintained for 14 min, and returned to initial conditions in $7 \mathrm{~min}$. The total run time was $47 \mathrm{~min}$. Data were acquired using the Varian MS Workstation data system. A splitting valve allowed a solvent flow of $0.2 \mathrm{ml} / \mathrm{min}$ from the HPLC to the electrospray source. LC-MS/MS analysis was performed in negative multiple reaction monitoring (MRM) mode. The mass spectra were obtained under the following conditions: a spray voltage of $4,500 \mathrm{~V}$, shield voltage of $600 \mathrm{~V}$, capillary voltage of $60 \mathrm{~V}$, nebulizing gas pressure of $50 \mathrm{psi}$, drying gas pressure of $18 \mathrm{psi}$, temperature of $230^{\circ} \mathrm{C}$ and electron multiplier voltage of $1,500 \mathrm{~V}$. The formation of product ions in the MS/MS experiments was induced by collision (CID) of the selected precursor $(3,4-$ dihydroxyphenylethanol=3,4-DHPEA m/z 153) with argon.

\section{Statistical analysis}

The differences between the two groups were tested by means of the GLM procedure (SAS, 2001) using the monofactorial model:

$$
\mathrm{Y}_{\mathrm{ij}}=\mu+\alpha_{\mathrm{i}}+\varepsilon_{\mathrm{ij}}
$$


where $\mu=$ general mean, $\alpha_{i}=\operatorname{diet}(i=1,2), \varepsilon_{i j}=$ error of model.

\section{RESULTS AND DISCUSSION}

\section{Characteristics of the stoned olive pomace and of the feedstuffs utilized}

The chemical characteristics of the DSOP are reported in Table 2. The protein content is similar to that reported by Malossini et al. (1983) and to the range found by MolinaAlcaide and Yañez-Ruiz (2008) in a previous review. The DSOP is characterized by a high level of ether extract $(206.6 \mathrm{~g} / \mathrm{kg} \mathrm{DM})$ and the fatty acids profile contains $75.5 \%$ C18:1cis9 as also reported by Chiofalo et al. (2002); the fibrous component was lower than the values reported by Molina-Alcaide and Yañez-Ruiz (2008) for olive cakes. In particular, the elimination of the stone determines a reduction in the ADL content: in earlier trials on depleted stoned olive pomace, Vaccarino et al. (1987), in a first and second trial, found 333.0 and $382.0 \mathrm{~g} / \mathrm{kg}$ DM of ADL while in virgin partially stoned pomace, Chiofalo et al. (2004), found $308.0 \mathrm{~g} / \mathrm{kg} \mathrm{DM}$ of ADL, $207.8 \mathrm{~g} / \mathrm{kg}$ DM represent a further reduction of one-third of this parameter. The reduction in lignin and the high content of ether extract determine an improvement in the dry matter digestibility (Sadeghi et al., 2009) and result in an energy content $(0.70$ Milk FU/kg DM) similar to that of the second cut alfalfa hay (0.67 Milk FU/kg DM) utilized in the trial. Nevertheless, the most interesting results are related to the phenolic composition of the DSOP that shows high amounts of secoiridoids, such as 3,4-dihydroxyphenylethanol (3,4DHPEA) (1.2 g/kg DM), 3,4-dihydroxyphenylethanol- elenolic acid di-aldehyde (3,4-DHPEA-EDA) $(12.6 \mathrm{~g} / \mathrm{kg}$ DM), p-hydroxyphenylethanol-elenolic acid di-aldehyde (pHPEA-EDA) $(5.6 \mathrm{~g} / \mathrm{kg} \mathrm{DM})$ and lignans, including 1acetoxypinoresinol. Several phenolic compounds occurring in the DSOP, such as 3,4-DHPEA, 3,4-DHPEA-EDA, pHPEA-EDA, are now considered to be the main bio-active phenols of extra-virgin olive oil that show a high antioxidant activity, which are also attributed as playing the main role in the link between olive oil consumption and the prevention of cardiovascular disease and cancer in humans (Servili et al., 2009; Covas, 2008; EFSA, 2011).

Table 3 reports the chemical composition and net energy of the feedstuffs and of the two diets used. Table 4 shows the tocopherol and tocotrienol content and the acidic composition of the lipid fraction of the feedstuffs used. It can be noted, with regard to the experimental concentrate, that there is a significant rise of $\alpha-T(p<0.05)$, of $\gamma$ e $\delta$-T $(\mathrm{p}<0.01)$ and of the total tocopherols $(62.88 \mathrm{vs} 55.87 \mu \mathrm{g} / \mathrm{g}$, $(\mathrm{p}<0.05)$, a good level of $\alpha-\mathrm{T}$ in the maize silage. The DSOP has had a positive effect on the acidic composition of the lipid fraction of the experimental concentrate with a significant decrease, with the exception of C18:0, of all the saturated fatty acids reported; there is an increase $(p<0.01)$ both in $\mathrm{C} 18: 1 \omega 9$ and for $\mathrm{C} 22: 6 \omega 3$, on the contrary there is a decrease $(\mathrm{p}<0.01)$ both of $\mathrm{C} 18: 2 \omega 6$ and of $\mathrm{C} 18: 3 \omega 3$ and $(\mathrm{p}<0.05)$ of $\mathrm{C} 20: 5 \omega 3$.

\section{Production and quality of the milk}

The ingestion of $17 \mathrm{~kg} \mathrm{DM} / \mathrm{d}$ per head for each group (Table 5) was constantly maintained for the duration of the trial, in this phase of lactation, this quantity represents the maximum ingestion capacity (Bartocci et al., 2006). The

Table 4. Tocopherols, tocotrienol $(\mu \mathrm{g} / \mathrm{g})$ and fatty acids $(\%)$ of the feedstuffs used

\begin{tabular}{|c|c|c|c|c|c|}
\hline & Alfalfa hay & Maize silage & Control concentrate & Experimental concentrate & Rmse \\
\hline$\alpha$-tocopherol & 2.36 & 43.32 & $45.64^{\mathrm{b}}$ & $50.26^{\mathrm{a}}$ & 1.33 \\
\hline$\gamma$-tocopherol & 0.16 & 2.79 & $1.59^{\mathrm{B}}$ & $2.72^{\mathrm{A}}$ & 0.19 \\
\hline$\delta$-tocopherol & - & 1.10 & $1.43^{\mathrm{B}}$ & $1.73^{\mathrm{A}}$ & 0.14 \\
\hline$\gamma$-tocotrienol & - & 7.94 & $7.21 *$ & $8.18 *$ & 0.47 \\
\hline Toc. totals & 2.52 & 55.15 & $55.87^{\mathrm{b}}$ & $62.88^{\mathrm{a}}$ & 2.17 \\
\hline \multicolumn{6}{|c|}{ Fatty acid profile } \\
\hline C10:0 & 0.24 & 0.06 & $0.20^{\mathrm{A}}$ & $0.07^{\mathrm{B}}$ & 0.01 \\
\hline $\mathrm{C} 12: 0$ & 1.04 & 0.39 & $1.34^{\mathrm{A}}$ & $0.56^{\mathrm{B}}$ & 0.03 \\
\hline $\mathrm{C} 14: 0$ & 1.76 & 0.57 & $0.71^{\mathrm{A}}$ & $0.49^{\mathrm{B}}$ & 0.02 \\
\hline $\mathrm{C} 16: 0$ & 29.01 & 17.20 & $17.13^{\mathrm{a}}$ & $15.01^{\mathrm{b}}$ & 0.40 \\
\hline C18:0 & 4.83 & 2.02 & 3.00 & 2.86 & 0.07 \\
\hline $\mathrm{C} 18: 1 \omega 9$ & 5.51 & 20.67 & $27.53^{\mathrm{B}}$ & $42.05^{\mathrm{A}}$ & 0.89 \\
\hline $\mathrm{C} 18: 2 \omega 6$ & 16.85 & 45.92 & $42.18^{\mathrm{A}}$ & $32.76^{\mathrm{B}}$ & 0.94 \\
\hline $\mathrm{C} 18: 3 \omega 3$ & 22.30 & 7.03 & $4.02^{\mathrm{A}}$ & $2.95^{\mathrm{B}}$ & 0.09 \\
\hline $\mathrm{C} 20: 4 \omega 6$ & 1.03 & 0.23 & 0.05 & 0.06 & 0.01 \\
\hline $\mathrm{C} 20: 5 \omega 3$ & 1.40 & 0.27 & $0.11^{\mathrm{a}}$ & $0.07^{\mathrm{b}}$ & 0.01 \\
\hline $\mathrm{C} 22: 6 \omega 3$ & 1.37 & 0.17 & $0.10^{\mathrm{B}}$ & $0.24^{\mathrm{A}}$ & 0.01 \\
\hline
\end{tabular}

${ }_{\mathrm{A}, \mathrm{B}} \mathrm{p}<0.01 ;{ }^{\mathrm{a}, \mathrm{b}} \mathrm{p}<0.05 ; * \mathrm{p}=6.28 \%$. 
Table 5. Live weight, body condition score, milk yield and quality

\begin{tabular}{lrcc}
\hline & Control & Experimental & Rmse \\
\hline DMI $(\mathrm{kg} / \mathrm{d})$ & 17.00 & 17.00 & - \\
LW $(\mathrm{kg})$ & 625.93 & 662.50 & 90.16 \\
ADG $(\mathrm{g} / \mathrm{d})$ & 421.88 & 437.50 & 391.47 \\
BCS $(1 \div 9)$ & 6.41 & 6.53 & 0.45 \\
Milk yield (kg/d) & 9.69 & 10.08 & 2.53 \\
Fat (\%) & 7.16 & 7.36 & 1.07 \\
Protein (\%) & 4.51 & 4.45 & 0.33 \\
Lactose $(\%)$ & 4.88 & 4.90 & 0.19 \\
Urea (mg/100 ml) & 32.58 & 33.13 & 3.22 \\
\hline
\end{tabular}

DMI = Dry matter intake; $\mathrm{LW}=$ Live weight $\mathrm{ADG}=$ Average daily gain; $\mathrm{BCS}=$ Body condition score.

milk production of the experimental group proved to be higher $(10.08$ and $9.69 \mathrm{~kg} / \mathrm{d})$ but the difference was not significant. Hadjipanyiotou (1999), feeding the olive byproduct in an experiment on dairy cows and Chiofalo et al. (2004) and Pauselli et al. (2007) on milk ewes did not find any differences between the milk produced by the control group and the experimental group. It should be stressed that the quantity of crude protein administered by DSOP per head was $110.60 \mathrm{~g} / \mathrm{d}(4.42 \%$ of the total protein) which as can be noted from the bibliography has a low digestibility determined by the presence of phenols (Waghorn and Schelton, 1997; Martin Garcia et al., 2003). Malossini et al. (1983) and Molina-Alcade and Yañez-Ruiz (2008) have reported respectively an apparent digestibility of crude proteins of 17.10 and of $10.00 \%$, but this low digestibility neither limited the milk production, which in fact proved to be higher, nor determined any changes in the BCS (6.41 vs 6.53 ), nor any negative variation in the average daily gain of the experimental group which was $437.50 \mathrm{~g} / \mathrm{d}$ with respect to $421.88 \mathrm{~g} / \mathrm{d}$ of the control group. Based on these results it could be assumed that due to the effect of the drying treatment of the DSOP, the apparent intestinal digestibility of rumen undegraded protein may undergo positive changes.

The fat, protein, lactose and urea content of the milk (Table 5) of the two groups is similar, respectively 7.16 and $7.36 \%, 4.51$ and $4.45 \%, 4.88$ and $4.90 \%, 32.58$ and $33.13 \mathrm{mg} / 100 \mathrm{ml}$. Thus the results obtained demonstrate, as found by Chiofalo et al. (2004) and Pauselli et al. (2007), that the experimental diet did not alter the level of the considered parameters. Therefore, what has already been asserted by Nefzaoui and Vanbelle (1986) and by Chiofalo et al. (2004) can be confirmed, which is that there is no adverse effect on the activity of the ruminal bacteria caused by the long-chain unsaturated fatty acids.

Table 6 reports the $\mathrm{pH}$, the milk coagulation parameters and the estimated production of mozzarella of the two groups. No significant differences were found for the $\mathrm{pH}$
Table 6. Milk quality and estimated yield of "mozzarella cheese"

\begin{tabular}{lrcr}
\hline & Control & Experimental & Rmse \\
\hline $\mathrm{pH}$ & 6.78 & 6.80 & 0.08 \\
$\mathrm{r}(\mathrm{min})$ & 20.34 & 22.35 & 4.15 \\
$\mathrm{~K}_{20}(\mathrm{~min})$ & 2.30 & 2.66 & 1.28 \\
$\mathrm{~A}_{30}(\mathrm{~mm})$ & 44.40 & 35.25 & 14.22 \\
Estimated "mozzarella cheese" & 2.28 & 2.40 & 0.59 \\
$\quad(\mathrm{~kg} / \mathrm{d})$ & & & \\
\hline $\mathrm{r}$ = Rennet clotting time; $\mathrm{K}_{20}=$ Curd firming time; $\mathrm{A}_{30}=$ Curd firmness.
\end{tabular}

values (6.78 and 6.80), for the rennet clotting time (20.34 and $22.35 \mathrm{~min}$ ), for the curd firming time (2.30 and 2.66 $\mathrm{min}$ ) and for the curd firmness (44.40 and $35.25 \mathrm{~mm}$ ). These data are similar to those obtained by Bartocci et al. (2006) and Tripaldi et al. (2010). The estimated production of mozzarella, in relation to the quantity and quality of the milk produced, was higher for the experimental group (2.40 and $2.28 \mathrm{~kg} / \mathrm{d}$ ). With regard to the results of the sensory evaluation of the bulk milk produced by the two groups, the evaluators gave an identical and positive assessment of the two milks which were both of a white porcelain colour, with a lactic smell and with a moderately persistent sweet flavour; therefore the stoned olive pomace did not result in any adverse effect on the characteristics of the milk listed above.

\section{Antioxidants and oxidative status of milk}

The occurrence of tocopherols and retinol in the milk of DSOP-treated and untreated animals is reported in Table 7 together with the milk TBARs values. Among tocopherols, only four $(\alpha-\mathrm{T}, \gamma-\mathrm{T}, \delta$-T and $\gamma$-T3) were present in appreciable quantities in the milk of both groups. Alpha-T was the highest present $(79.42 \%)$, followed by $\mathrm{y}-\mathrm{T}$ $(15.93 \%)$ and $\delta$-T $(1.98 \%)$ in the milk of the control group. The DSOP dietary supplementation resulted in a significant increase in all the aforementioned tocopherols, except for $\delta$-T, in the milk of the treated group without altering their distribution. As a consequence, the total amount of milk vitamin $\mathrm{E}$ was 8.60 and $10.45 \mu \mathrm{g} / \mathrm{g}$ fat $(\mathrm{p}<0.01)$ for the

Table 7. Tocopherols, tocotrienol, retinol and oxidative stability of the lipid fraction of the milk of the two groups

\begin{tabular}{lccc}
\hline & Control & Experimental & Rmse \\
\hline$\alpha$-tocopherol $(\mu \mathrm{g} / \mathrm{g}$ fat $)$ & $6.83^{\mathrm{b}}$ & $8.19^{\mathrm{a}}$ & 1.00 \\
$\gamma$-tocopherol $(\mu \mathrm{g} / \mathrm{g}$ fat $)$ & $1.37^{\mathrm{B}}$ & $1.70^{\mathrm{A}}$ & 0.21 \\
$\delta$-tocopherol $(\mu \mathrm{g} / \mathrm{g}$ fat $)$ & 0.17 & 0.19 & 0.03 \\
$\gamma$-tocotrienol $(\mu \mathrm{g} / \mathrm{g}$ fat $)$ & $0.23^{\mathrm{B}}$ & $0.37^{\mathrm{A}}$ & 0.05 \\
Toc. totals $(\mu \mathrm{g} / \mathrm{g}$ fat $)$ & $8.60^{\mathrm{B}}$ & $10.45^{\mathrm{A}}$ & 1.12 \\
Retinol $(\mu \mathrm{g} / \mathrm{g}$ fat $)$ & $2.54^{\mathrm{B}}$ & $3.17^{\mathrm{A}}$ & 0.28 \\
TBARs $(\mu \mathrm{g}$ MDA/g fat $)$ & $15.05^{\mathrm{A}}$ & $12.09^{\mathrm{B}}$ & 1.79 \\
\hline
\end{tabular}

${ }_{\mathrm{A}, \mathrm{B}} \mathrm{p}<0.01 ;{ }^{\mathrm{a}, \mathrm{b}} \mathrm{p}<0.05$.

TBARs $=$ Reactive substances with tiobarbituric acid; MDA = Malondialdehyde 
control and the treated group respectively. These results may be ascribed to the occurrence of a higher amount of vitamin $\mathrm{E}$ in the experimental concentrate (62.88 vs 55.87 $\mu \mathrm{g} / \mathrm{g}, \mathrm{p}<0.05)$. These findings are consistent with Weiss et al. (2003), who showed evidence of the relationship between dietary $\alpha$-T content and its concentration in milk independently from the tested fat sources. The high amount of phenols characterized by strong antioxidant activity, such as 3,4-DHPEA, 3,4-DHPEA-EDA, found in the DSOP, might also be implicated in the increase in the amount of $\alpha-T$ in the milk. In fact, the DSOP phenolic antioxidants can protect tocopherols from oxidation thereby increasing the total amount absorbed through digestion and thus their concentration in the milk. In this regard, an important achievement was the detection and partial characterization of hydrophilic phenols in the milk. Figure 1 reports the LCMS/MS chromatogram and the mass spectra that substantiate the occurrence of 3,4-DHPEA in the milk of water buffaloes fed with DSOP, while the other phenols, such as 3,4-DHPEA-EDA, p-HPEA-EDA and lignans, which are the most concentrated compounds of DSOP, were not found in the milk of DSOP-fed animals. It is nevertheless plausible that 3,4-DHPEA-EDA, very abundant in DSOP, is hydrolyzed during digestion, releasing the 3,4-DHPEA that can be transferred to and accumulate in the milk. In terms of the absolute concentration of 3,4-DHPEA found in the milk of water buffaloes treated with DSOP, the average value was 36.0 $\mu \mathrm{g} / \mathrm{L}$, but the disparity due to subject variability was very large, ranging between a minimum of 8.9 and a maximum of $56.2 \mu \mathrm{g} / \mathrm{L}$.

The milk from DSOP-fed animals also revealed a higher retinol level (3.17 vs $2.54 \mu \mathrm{g} / \mathrm{g}$ fat, $\mathrm{p}<0.01)$ in comparison to the milk from the control group. The higher amount of tocopherols and retinol might have contributed to reducing the level of TBARs (12.09 vs $15.05 \mu \mathrm{g}$ MDA/g fat, $\mathrm{p}<0.01)$ in the milk of the treated group and consequently to a better oxidative status of this milk with respect to the milk derived from the untreated animals. These results are consistent with those reported by Pauselli et al. (2007) in the milk of ewes fed with a concentrate enriched with stoned olive pomace. The presence of a powerful natural antioxidant such as 3,4-DHPEA in the milk of DSOP-fed animals, an antioxidant that is naturally occurring in virgin olive oil and its by-products, might also contribute to the better oxidative status of milk fat from the DSOP-treated group, acting either directly or indirectly (synergism with vitamin E) against free radicals (Owen and Giacosa, 2000; Mirò Casas et al., 2001; Servili et al., 2004). Following the addition of green tea phenolic extracts to the milk, Schamberger et al. (2007) observed a reduction in the Maillard reactionderived products in UHT milk, and Gramza-Michalowska et al. (2007) described an increase in the antioxidant activity of butter, also due to green tea extract addition during butter processing. Among DSOP phenols, ortho-diphenols, such as 3,4-DHPEA and 3,4-DHPEA-EDA, are known to possess the highest antioxidant activity and are also effective radical scavengers (Baldioli et al., 1996). In particular, 3,4-DHPEA scavenges aqueous peroxyl radicals near the membrane surface, while oleuropein scavenges chain-propagating lipid peroxyl radicals within membranes (Saija et al., 1998). Moreover, phenolic compounds have been shown to play a role in vitamin E recycling and might have also accounted for the higher milk tocopherol levels in the DSOP-treated group. A similar hypothesis has been formulated for flavonoids on $\alpha$-T recycling (Zhu et al., 1999; Pedrielli and

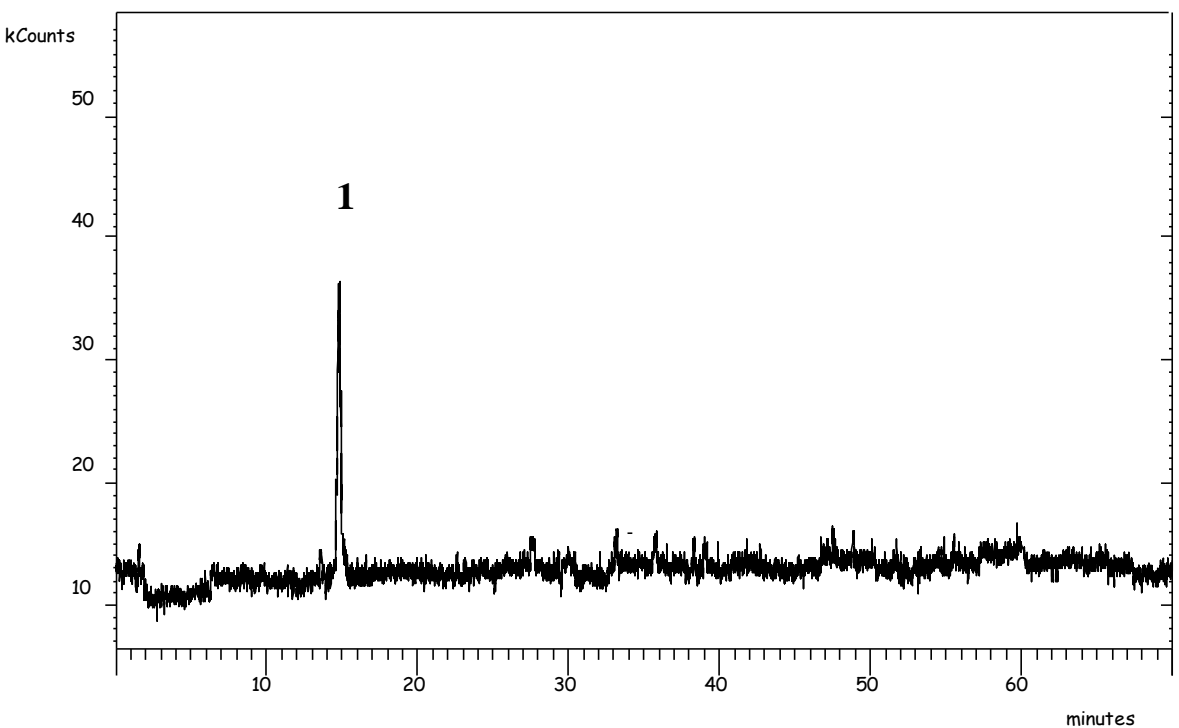

Figure 1. HPLC-ESI-MS/MS chromatogram obtained from a milk sample produced by a DSOP-fed buffalo cow. [1] 3,4-DHPEA = 3,4dihydroxyphenylethanol (hydroxytyrosol). 
Skibsted, 2002; Pazos et al., 2005). Nevertheless, further studies are required to better clarify the role of each DSOP compound in the total milk antioxidant capacity.

\section{Milk fatty acids composition}

Table 8 presents the fatty acid composition of the lipid fraction of the milk. A significant difference was found in favour of the experimental group $(\mathrm{p}<0.05)$ for $\mathrm{C} 18: 0$, $\mathrm{C} 18: 3 \omega 6$ and $(\mathrm{p}=8.67 \%)$ for $\mathrm{C} 18: 1 \omega 7$ and a larger amount of $\mathrm{C} 18: 1 \omega 9$. While the increase of $\mathrm{C} 18: 0$ could derive from the bacterial biohydrogenation activity (Mosley et al., 2002), the increase of $\mathrm{C} 18: 1 \omega 9$, apart from the DSOP, could in part be attributed to the activity of desaturation of the mammary

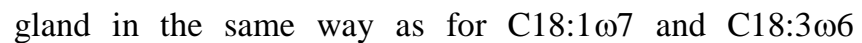
(Chilliard and Ferlay, 2004). In dairy cows $40 \%$ of the $\mathrm{C} 18: 1 \omega 9$ is formed in the mammary gland by $\Delta^{9}$-desaturase

Table 8. Acid composition (\%) of the milk fat of the two groups

\begin{tabular}{|c|c|c|c|}
\hline & Control & Experimental & Rmse \\
\hline C6:0 & 5.20 & 4.72 & 1.00 \\
\hline C8:0 & 3.17 & 2.74 & 0.79 \\
\hline C10:0 & 4.08 & 3.72 & 1.01 \\
\hline C12:0 & 4.31 & 3.95 & 0.56 \\
\hline C14:0 & 14.43 & 14.30 & 1.02 \\
\hline C16:0 & 34.10 & 33.53 & 2.91 \\
\hline C18:0 & $7.34^{\mathrm{b}}$ & $8.60^{\mathrm{a}}$ & 0.93 \\
\hline 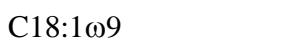 & 16.83 & 17.81 & 2.58 \\
\hline $\mathrm{C} 18: 1 \omega 7$ & $0.96^{*}$ & $1.27 *$ & 0.33 \\
\hline $\mathrm{C} 18: 2 \omega 6$ & 2.15 & 2.29 & 0.39 \\
\hline $\mathrm{C} 18: 3 \omega 3$ & 0.43 & 0.46 & 0.08 \\
\hline $\mathrm{C} 18: 3 \omega 6$ & $0.06^{\mathrm{b}}$ & $0.09^{\mathrm{a}}$ & 0.02 \\
\hline $\mathrm{C} 18: 4 \omega 3$ & 0.45 & 0.52 & 0.11 \\
\hline 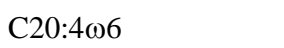 & 0.18 & 0.20 & 0.08 \\
\hline $\mathrm{C} 20: 5 \omega 3$ & 0.07 & 0.06 & 0.03 \\
\hline $\mathrm{C} 22: 6 \omega 3$ & 0.04 & 0.03 & 0.03 \\
\hline SFA & 74.52 & 73.30 & 2.97 \\
\hline MUFA & 21.08 & 22.15 & 2.69 \\
\hline PUFA & 4.40 & 4.55 & 0.74 \\
\hline SFA/UFA & 3.04 & 2.75 & 0.41 \\
\hline$\omega 3$ & 1.47 & 1.45 & 0.42 \\
\hline$\omega 6$ & 3.47 & 3.64 & 0.46 \\
\hline$\omega 6 / \omega 3$ & 2.40 & 2.51 & 0.26 \\
\hline Atherogenic index & 3.84 & 3.60 & 0.57 \\
\hline Thrombogenic index & 3.87 & 3.75 & 0.51 \\
\hline $\begin{array}{l}\text { Short chain } \\
\text { (C6:0-C10:0) }\end{array}$ & 12.35 & 10.93 & 2.53 \\
\hline $\begin{array}{l}\text { Medium chain } \\
(\mathrm{C} 11: 0-\mathrm{C} 16: 3 \omega 4)\end{array}$ & 57.56 & 56.17 & 3.11 \\
\hline $\begin{array}{l}\text { Long chain } \\
\text { (C17:0-C24:1) }\end{array}$ & 30.09 & 32.90 & 3.69 \\
\hline
\end{tabular}

${ }_{\mathrm{a}, \mathrm{b}} \mathrm{p}<0.05 ; * \mathrm{p}=8.67 \%$.

SFA $=$ Saturated fatty acids; MUFA = Monounsaturated fatty acids; PUFA = Polyunsaturated fatty acids; UFA = Unsaturated fatty acids . activity (Lock and Gainsworth, 2003). The milk fatty acid composition of the experimental group is proved to be similar to that observed by Selner and Schultz (1980) in cattle fed with rumen unprotected oleic acid sources.

The DSOP determined an increase of the MUFA represented principally by $\mathrm{C} 18: 1 \omega 9$ and of the PUFA represented principally by $\mathrm{C} 18: 2 \omega 6$ at the expense of the SFA. Consequently, there was a reduction of saturated/unsaturated ratio $(2.75$ and 3.04$)$, of the atherogenic (3.60 and 3.84) and thrombogenic indices (3.75 and 3.87) of the milk produced by the experimental group. Similar results were obtained on the fatty acid composition of milk fat of sheep and on the indices by Chiofalo et al. (2004) and Pauselli et al. (2007). In the milk fat of the experimental group there was a reduction of the short-chain fatty acids (C6:0-C10:0) and medium-chain fatty acids (C11:0-C16:3 04$)$ and an increase of the long-chain fatty acids (C17:0-C24:1). These results could have been determined by the increased intake by the udder of fatty acids of food origin and by the protective effect of the vitamin $\mathrm{E}$ from the oxidation on the long-chain fatty acids (Chiofalo et al., 2004).

\section{CONCLUSIONS}

Dried stoned olive pomace, in the quantity utilized, can be used in the feeding of the lactating buffalo without reduction in the quantity of milk produced and without negative effects on its quality, since the chemical composition and cheese making properties remain practically unchanged.

Further, the dietetic-nutritional characteristics of the milk are improved due to a greater contribution of tocopherols, retinol and the presence of hydroxytyrosol, in addition to a better fatty acid composition determined by a decrease in the saturated/unsaturated ratio of the atherogenic and thrombogenic indices.

\section{ACKNOWLEDGEMENTS}

This work was financially supported by the Italian Ministry of Agricultural and Forest Policy (MiPAF) within the Project "VALOROLIO".

\section{REFERENCES}

Altiero, V., L. Moio, and F. Addeo. 1989. Estimate of mozzarella yield based on the fat and protein content of buffalo milk. Sci. Tec. Latt.- Casearia 40:425-433.

AOAC. 1995. Official methods of analysis, 16th edn. Association of Official Analytical Chemists, Washington, DC.

ASPA. 1995. Method of milk analysis of the main zootechnical species. Università degli Studi di Perugia, Italy.

Baldioli, M., M. Servili, G. Perretti, and G. Montedoro. 1996. 
Antioxidant activity of tocopherols and phenolic compounds of virgin olive oil. J. Am. Oil Chem. Soc. 73:1589-1593.

Bartocci, S., S. Terramoccia, and C. Tripaldi. 2006. The utilization of a high level energy/protein diet for lactating Mediterranean buffaloes: intake capacity and effects on quanti-qualitative milk parameters. Livest. Sci. 99:211-219.

Bartocci, S., C. Tripaldi, and S. Terramoccia. 2002. Characteristic of foodstuffs and diet, and quanti-qualitative milk parameters of Mediterranean buffaloes bred in Italy using the intensive system. An estimate of the nutritional requirements of buffalo herds lactating or dry. Livest. Prod. Sci. 77:45-58.

Borghese, A., and M. Mazzi. 2005. Buffalo population and strategies in the world. In Buffalo Production and Research, edn. FAO, Rome, pp. 1-39.

Campanile, G., C. De Filippo, R. Di Palo, W.Taccone, and L. Zicarelli. 1998. Influence of dietary protein on urea levels in blood and milk of buffalo cows. Livest. Prod. Sci. 55:135-143.

Chilliard, Y., and A. Ferlay. 2004. Dietary lipids and forages interactions on cow and goat milk fatty acid composition and sensory properties. Reprod. Nutr. Dev. 44:467-492.

Chiofalo, B., L. Liotta, V. Chiofalo, and A. Zumbo. 2002. Olive cake for ewe feeding: effect on the milk acid composition. In: Proceeding of the 15th National Congress of S.I.P.A.O.C., Cagliari Italy, pp. 136-137.

Chiofalo, B., L. Liotta, A. Zumbo, and V. Chiofalo. 2004. Administration of olive cake for ewe feeding: Effect on milk yield and composition. Small Rum. Res. 55:169-176.

Commission Regulation (EC) No 1989/2003 of 6 November 2003 amending Regulation (EEC) No 2568/91 on the characteristics of olive oil and olive-pomace oil and on the relevant methods of analysis.

Covas, M. I. 2008. Bioactive effects of olive oil phenolic compounds in humans: reduction of heart disease factors and oxidative damage. Inflammopharmacology 16:216-221.

EFSA. 2011. Panel on dietetic products, nutrition and allergies (NDA). Polyphenols in olive related health claims. EFSA J. 9:2033.

Fenaille, F., P. Mottier, R. J. Turesky, S. Ali, and P. A. Guy. 2001. Comparison of analytical techniques to quantify malondialdehyde in milk powders. J. Chromatogr. 921:237245.

Goering, H. K., and P. J. Van Soest. 1970. Forage fibre analysis (apparatus, reagents, procedures and some applications). ARS USDA Agriculture Hand Book $N^{\circ} 379$, Washington, DC.

Gramza-Michalowska, A., J. Korczak, and J. Regula. 2007. Use of plant extracts in summer and winter season butter oxidative stability improvement. Asia Pac. J. Clin. Nutr. 16:85-88.

Hadjipanayjotou, M. 1999. Feeding ensiled crude olive cake to lactating Chios ewes, Damascus goats and Friesan cows. Livest. Prod. Sci. 59:61-66.

Havemose, M. S., M. R. Weisbjerg, W. L. P. Bredie, and J. H. Nielsen. 2004. Influence of feeding different types of roughage on the oxidative stability of milk. Int. Dairy J. 14:563-570.

INRA. 1998. Alimentation des bovines, ovins et caprins. INRA Publ., Paris, France.

Lock, A., and P. C. Garnsworthy. 2003. Seasonal variation in milk conjugated linoleic acid and 9-desaturase in dairy cows. Livest. Prod. Sci. 79:47-59.
Malossini, F., M. Verna, and D. Settineri. 1983. Valore nutritivo di alimenti diversi espressi in UF tradizionali e secondo i nuovi sistemi energetici. Seminario ASPA, la stima del valore nutritivo degli alimenti, metodi classici e concezioni moderne. Roma 20-21/9/1983.

Martin-Garcia, A. I., A. Moumen, P. R. Yañez-Ruiz, and E. Molina-Alcaide. 2003. Chemical composition and nutrients availability for goats and sheep of two-stage olive cake and olive leaves. Anim. Feed Sci. Technol. 107:61-74.

Mirò-Casas, E., A. M. Farré, and M. I. Covas. 2001. Capillary gas chromatography-mass spectrometry quantitative determination of hydroxytyrosol and tyrosol in human urine after olive oil intake. Anal. Biochem. 294:63-72.

Molina-Alcaide, E., and P. R. Yañez-Ruiz. 2008. Potential use of olive by products in ruminant feeding: A review. Anim. Feed Sci. Technol. 147:247-264.

Mosley, E., G. L. Powell, M. B. Riley, and T. C. Jenkins. 2002. Microbial biohydrogenation of oleic acid to trans isomers in vitro. J. Lipid Res. 43:290-296.

Nefzaoui, A., and M. Vanbelle. 1986. Effects of feeding alkalitreated olive cake on intake, digestibility and rumen liquor parameters. Anim. Feed Sci. Technol. 14:139-149.

Owen, R. W., W. A. Mier, and A. Giacosa. 2000. Phenolic compounds and squalene in olive oils: the concentration and antioxidant potential of total phenols, secoiridoids, lignans and squalene. Food Chem. Toxicol. 38:647-659.

Pazos, M., M. J. Gonzalez, J. M. Gallardo, J. L. Torres, and I. Medina. 2005. Preservation of the endogenous antioxidant system of fish muscle by grape polyphenols during forzen storage. Eur. Food Res. Technol. 220:514-519.

Pauselli, M, M. Servili, S. Esposto, G. Gervasi, E. Mourvaki, A. Taticchi, S. Urbani, R. Selvaggini, L. Concezzi, and G. Montedoro. 2007. Effect of destoned olive cake as animal feed on ewe milk quality. Proc. Int. Conf. "New technologies for the treatment and valorization of agro by-products", ISRIM, Terni, 3-5 Oct. 2007.

Pedrielli, P., and L. Skibsted. 2002. Antioxidant synergy and regeneration effect of Quercetin, (-)-Epicatechin, and (+)Catechin on a-Tocopherol in homogeneous solutions of peroxidating methyl linoleate. J. Agric. Food Chem. 50:71387144.

Puppo, S., S. Bartocci, S. Terramoccia, F. Grandoni, and A. Amici. 2002. Rumen microbial counts, and in vivo digestibility in buffaloes and cattle given different diets. Anim. Sci. 72:323329

Risvik, E., R. Popper, and R. Rogers. 1989. Expert systems and their application in sensory evaluation. Food Qual. Prefer. 1:183-184.

Sadeghi, H., A. T. Yansari, and Z. Ansari-Pirsarai. 2009. Effects of different olive cake by products on dry matter intake, nutrient digestibility and performance of Zel sheep. Int. J. Agric. Biol. 11:39-43.

Saija, A., D. Trombetta, A. Tomaino, R. Lo Cascio, P. Princi, N. Uccella, F. Bonina, and F. Castelli. 1998. In vitro evaluation of the antioxidant activity and biomembrane interaction of the plant phenols oleuropein and hydroxytyrosol. Int. J. Pharm. 166:123-133.

SAS (Statistical Analysis System Institute). 2001. SAS User's 
Guide, Statistics, SAS Institute Inc., Cary, NC.

Schamberger, G. P., and T. P. Labuza. 2007. Effect of green tea flavonoids on Maillard browing in UHT milk. LWT - Food Sci. Technol. 40:1410-1417.

Selner, D. R., and L. H. Schultz. 1980. Effects of feeding oleic acid or hydrogenated vegetable oils to lactating cows. J. Dairy Sci. 63:1235-1241.

Servili, M., R. Selvaggini, S. Esposto, A. Taticchi, G. Montedoro, and G. Morozzi. 2004. Health and sensory properties of virgin olive oil hydrophilic phenols: agronomic and technological aspects of production that affect their occurrence in the oil. J. Chromatogr. A 1054:113-127.

Servili, M., M. Pauselli, A. Dal Bosco, C. Castellini, S. Esposto, A. Taticchi, S. Urbani, F. Mariucci, and G. Montedoro. 2007. Sanse vergini promosse a integratori mangimistici. Olivo e Olio 7-8: 42-47.

Servili, M., S. Esposto, R. Fabiani, S. Urbani, A. Taticchi, F. Mariucci, R. Selvaggini, and G. Montedoro. 2009. Phenolic compounds in olive oil: antioxidant, health and sensory activities according to their chemical structure. Inflammopharmacology 17:76-84.

Servili, M., S. Esposto, S. Urbani, A. Taticchi, and M. Petruccioli. 2011. Utilizzazione dei reflui oleari. In Oleum, Ed agricole, p. 174.

Tripaldi, C., G. Palocci, M. Miarelli, M. Catta, S. Orlandini, S. Amatiste, R. Di Bernardini, and G. Catillo. 2010. Effects of mastitis on buffalo milk quality. Asian-Aust. J. Anim. Sci. 23:1319-1324.

Ulbricht, T. L. V., and D. A. T. Southgate. 1991. Coronary heart disease: seven dietary factors. The Lancet 338:985-992.
Vaccarino, C., M. M. Tripodo, I. Salvo, G. Laganà, M. Verna, V. Pace, and S. Bartocci. 1987. Un nuovo processo per la valorizzazione delle sanse e delle acque di vegetazione. Nota 1 , Pretrattamento delle sanse con $\mathrm{Na}_{2} \mathrm{CO}_{3}$. Riv. Ital. Sost. Gras. 64:535-539.

Van Soest, P. J., J. B. Robertson, and B. A. Lewis. 1991. Methods for dietary fiber, neutral detergent fiber and nonstarch polysaccharides in relation to animal nutrition. J. Dairy Sci. 74:3583-3597.

Vera, R., C. Aguilar, R. Lira, P. Toro, L. Barrales, I. Peña, F. Squella, P. Pérez, J. Quenaya, H. Yutronic, and I. Briones. 2009. Feeding dry olive cake modifies subcutaneous fat composition in lambs, noting cake resistance to degradation and peroxidation. Chil. J. Agric. Res. 69:548-559.

Waghorn, G. C., and I. D. Shelton. 1997. Effect of condensed tannins in Lotus corniculatus on nutritive value for sheep. J. Agric. Sci. 128:365-372.

Wagner, J. J., K. S. Lusby, J. W. Oltjen, J. Rakestraw, R. P. Wetteman, and L. E. Walters. 1988. Carcass composition in mature Hereford cows. Estimation an effect on daily metabolizable energy requierement during winter. J. Anim. Sci. 66:603-612.

Weinberg, Z. G., Y. Chen, and P. Weinberg. 2008. Ensiling olive cake without molassed for ruminant feeding. Bioresour. Technol. 99:1526-1529.

Weiss, W. P., and D. J. Wyatt. 2003. Effect of dietary fat and vitamin $\mathrm{E}$ on $\alpha$-tocopherol in milk from dairy cows. J. Dairy Sci. 86:3582-3591.

Zannoni, M., and S. Annibaldi. 1981. Standardization of the renneting ability of milk by Formagraph. Sci. Tecn. Latt.Casearia 32:79-94.

Zhu, Q. Y., Y. Huang, D. Tdang, and Z. Chen. 1999. Regeneration of a-tocopherol in human low-density lipoprotein by green tea catechin. J. Agric. Food Chem. 47:2020-2025. 